Article

\title{
Design and Verification of a Simple Approach to Brownfields Categorization
}

\author{
Barbara Vojvodíková $^{1, * \mathbb{D}}$, Radim Fojtík $^{1} \mathbb{D}$ and Iva Tichá ${ }^{2}$ \\ 1 Faculty of Civil Engineering, VSB-Technical University of Ostrava, 70800 Ostrava, Czech Republic; \\ radim.fojtik.st@vsb.cz \\ 2 Faculty of Social Studies, University of Ostrava, 70200 Ostrava, Czech Republic; iva.ticha@osu.cz \\ * Correspondence: barbara.vojvodikova@vsb.cz; Tel.: +420-7251-17244
}

Citation: Vojvodíková, B.; Fojtík, R.; Tichá, I. Design and Verification of a Simple Approach to Brownfields Categorization. Sustainability 2021, 13, 11206. https://doi.org/10.3390/ su132011206

Academic Editor: Robert Krzysztofik

Received: 27 August 2021

Accepted: 2 October 2021

Published: 11 October 2021

Publisher's Note: MDPI stays neutral with regard to jurisdictional claims in published maps and institutional affiliations.

Copyright: (c) 2021 by the authors. Licensee MDPI, Basel, Switzerland. This article is an open access article distributed under the terms and conditions of the Creative Commons Attribution (CC BY) license (https:// creativecommons.org/licenses/by/ $4.0 /)$.

\begin{abstract}
Brownfields have been the subject of research, evaluation, categorization and, of course, redevelopment for many years. The ABC(D) model (an assessment tool to identify different types of sites in terms of their potential) by the Concerted Action on Brownfield and Economic Regeneration Network (CABERNET) has been mentioned in many publications. The aim of the assessment method presented in this article is to use the basic essence of the categories in the ABC(D) model and to use our own very simple criteria. Our criteria are the result of many years of experience in the creation and management of the brownfield database. In 2017, the development potential of selected brownfields in the database of the Moravian-Silesian region (Czech Republic) was evaluated using our proposed procedure (three objective and one subjective criterion). In 2020, verification of the categories in regard to how correctly or incorrectly they were proposed was carried out. The results from this verification, including reasons for the accompanying inaccuracies, are a part of this article. We verified that the very simple evaluation procedure we proposed is functional and can be applied by database administrators continuously without the need to create complex datasets and statistical evaluations.
\end{abstract}

Keywords: brownfields; $\mathrm{ABC}(\mathrm{D})$ model; criteria; brownfield regeneration; postindustrial areas; evaluation

\section{Introduction}

This article is based on the 20 years of experience of the authors in the field of evaluation and development of evaluation models aimed at the regeneration of brownfields. The first one was presented in 2001 [1]. In the following years, several databases of brownfields in the Czech Republic were evaluated based on different approaches [2-7]. In the search for the optimal procedure and criteria, it was clearly established that it is very necessary to have at least a general overview of the potential of brownfields in the area, this potential must be very easy to illustrate and above all it must be very quickly evaluated [8,9]. This idea has also been mentioned in several informal discussions with city or county staff who do not have the time or space to search for lots of information or apply complex mathematical models. Their great potential is precisely the deep knowledge of place and context.

In recent years, several different and mostly very complex models containing many criteria have been published for use in the Czech Republic [10,11]. Often, they use only a few indicators [12] but assume the addition of other factors. These models have been applied to selected regions using various analytical tools. These models are input-intensive, the staff of the regions or cities that manage the brownfields databases do not have the time and sometimes not even the resources to keep the information up to date. Therefore, new sites are not evaluated and brownfields that are already classified and evaluated are not updated when changes occur. This makes the whole evaluation system inaccurate and therefore practically unusable over a period of several years. Based on the experience with the creation of brownfield databases, it was verified that the $\mathrm{ABC}(\mathrm{D})$ model [13] is the best 
fit for explaining the potential of brownfields for further regeneration. Some of the authors of the article participated in the creation and evaluation of the database of brownfields in the city of Ostrava in 2000 and its first update in 2010. They have been involved in the preparation of the information structure and evaluation of the Moravian-Silesian database since 2008.

The ABC(D) model concept is well known by most experts who publish in the brownfield field. Therefore, this introductory information is intended primarily for those who are new to brownfields.

One of the first European approaches to defining the concept of brownfields was created within the European working group CLARINET (Contaminated Land Rehabilitation Network for Environmental Technologies). The work of this group was followed by CABERNET. The member of CABERNET network are the authors of the now traditionally used "ABC model" [14,15]. Many of their followers refer to these works [16-19]. When applying this model, the target is to identify the potential for the regeneration of brownfields in a particular area. The resulting dataset is a useful tool not only for public administration but also for the private sector $[20,21]$.

The ABC model was later extended to include category D. This category has been listed in the literature in the brownfield handbook [22] since 2006. A team from the Slovak University of Technology in Bratislava [23] participated in defining this category. However, in the same year another, albeit similar, approach to defining category D appeared in [24]. It is therefore clear that there has been a need at the European level to single out certain types of sites and to deal with them separately.

The ABC (CABERNET) model defines three types of brownfields according to their potential for regeneration. The definition of each category is as follows:

Sites A: Such sites and buildings are highly economically profitable and the most feasible, especially for the private sector. Therefore, they have the greatest potential for regeneration. The definition is usually supplemented with additional ideas for example The redevelopment of these sites creates a clear increase in site value there is no requirement for public support or intervention [25]. Sites B: areas and buildings, of which the regeneration possible, that are not profitable enough for the private sector to participate in their regeneration independently. The public and private sector (Public-Private Partnership-PPP) are expected to work together in their regeneration [26,27]. Risk sharing, coordinated planning and shared financing of projects through public-private initiatives are characteristic of many urban regeneration interventions on such sites [25].

Sites marked as $C$ refer to areas and buildings where the expected costs of revitalization significantly exceed the economic benefits. Revitalization is not profitable; it depends mainly on public sector projects or government institutions. Public finance should be an incentive. This incentive may be specific legislative instruments, e.g., tax incentives. [28], or the financing of some steps of the regeneration of a site so that it can be shifted to category B [29].

The general description is accepted by most theoreticians and practitioners. However, they differ in criteria classifying brownfields into categories. The Table 1 lists some of the approaches defined in the Czech Republic.

Table 1. The approaches for classification defined in the Czech Republic.

\begin{tabular}{cr}
\hline Author & \multicolumn{1}{c}{ Criteria } \\
\hline Jackson, et al. 2004 [20] & $\begin{array}{l}\text { A key indicator is the location (position in urban structure) of the } \\
\text { site. Areas in the center and good transport availability are much } \\
\text { more interesting (category A) than those on the outskirts or those } \\
\text { with poor transport accessibility (category C). }\end{array}$ \\
\hline
\end{tabular}


Table 1. Cont.

\begin{tabular}{|c|c|}
\hline Author & Criteria \\
\hline Jackson, et al. 2004 [20] & $\begin{array}{l}\text { A key indicator is the location (position in urban structure) of the } \\
\text { site. Areas in the center and good transport availability are much } \\
\text { more interesting (category A) than those on the outskirts or those } \\
\text { with poor transport accessibility (category C). }\end{array}$ \\
\hline Doleželová et al. 2014 [28] & $\begin{array}{l}\text { Sites with a real estate sale ability coefficient greater than } 1.1 \text { can } \\
\text { be considered unequivocally commercially attractive for investors } \\
\text { even without grant funding (unless excessive real burdens or } \\
\text { investment risks exist). These sites belong to category A. } \\
\text { Another group, classified B, contains sites with the sale ability } \\
\text { coefficient equal to or smaller than } 1.1 \text {, but greater than } 0.75 \text {. The } \\
\text { remaining sites with a sale ability coefficient less than } 0.75 \text { make } \\
\text { up the group of unprofitable projects, marked as category C }\end{array}$ \\
\hline Votoček, 2011 [29] & $\begin{array}{l}\text { Category A: are brownfields absorbed by the private sector itself. } \\
\text { They have a good lo-cation due to the layout of the municipality. } \\
\text { They have a small or negligible environ-mental burden, the } \\
\text { development of the municipality does not require a larger } \\
\text { development area in this place for the needs of the public sector. } \\
\text { There is also a good ownership structure in the neighborhood. } \\
\text { Category B: there are brownfields with more risks and problems. } \\
\text { The private sector is no longer capable of independently ensuring } \\
\text { their development. Cooperation in the form of mutual support } \\
\text { between the public and private sectors must be sought. } \\
\text { Category C: are areas whose development the private sector is } \\
\text { unable to ensure. However, their existence can block the } \\
\text { development of the municipality, or represent an irreplaceable } \\
\text { location for the necessary development of public goods. } \\
\text { Long-term neglect of such an area brings social, economic, and } \\
\text { ecological problems to the municipality. }\end{array}$ \\
\hline
\end{tabular}

Category $\mathrm{D}$ is special and is designed differently from the others. According to some authors, these are sites where there will be no redevelopment, as neither the private sector nor the public one is willing or able to invest in the site [24]. According to the experience in Germany, the reason for the lack of interest in both the private and public sectors is the need to invest vast sums of money, regardless of what barriers to development these areas pose [30]. In addition to reluctance and lack of interest, some authors consider the issue of high levels of contamination as a key indicator for the economic aspect of the regeneration process to be key for inclusion in category D [31-33].

It is important that the criteria for assignment to $A B C$ categories are as simple and easy to update as possible, while sufficiently affecting the site's potential for regeneration. We assumed that it was possible to create a system for assessing the potential of brownfields that would be simple, easy to apply, and at the same time provide the right results. After almost 10 years of active work with the Moravian-Silesian brownfield database, the authors have developed a very simple method of assessment (categorization into ABC(D) categories), which does not require complex formulas, complicated information gathering or statistical evaluation. The whole system is based on three objective and one subjective criterion as described further in the methods section. Based on the verification with an interval of 3 years (the results of verification are mentioned in Section 3, "Results"), we prove that our method is a functional and effective.

\section{Materials and Methods}

Many approaches have been taken in the past to categorize brownfield sites. One idea close to the authors' approach is an assessment based on the variability of functions in time and space, and the specifics of locational conditions. However, the main distinction is made based on past use and contamination rates [34]. In general, we found this approach 
inspiring. The financial factor (need for public finance input) is often mentioned as a key indicator [35]. The authors' aim was to identify sites that need this intervention but not to make a distribution based on this criterion.

Additionally, their approach to classification is interesting, which is based on both the characteristics of the sites and their distribution by region. However, the classification is focused only on industrial areas [36] and therefore could not be used.

For the $\mathrm{ABC}$ category, we primarily tested and drew inspiration from the authors listed in Table 1. The choice of the Czech authors' approach is a logical consequence of the fact that the model is applied in the Czech Republic.

Doleželová's [28] approach seemed to be the most accurate. In her concept, the author works with specific figures and intervals often based on condition of building on site. On a few sites was tested this approach. It was evaluated that detailed economic analyses of individual sites are costly and time-consuming. It was further confirmed that the condition of abandoned buildings is deteriorating very quickly. It would therefore be necessary to repeat this costly procedure frequently to maintain the functionality of the whole evaluation. For these reasons, Doleželová's approach was denied.

Using Jackson's [20] approach to categorization is inspiring. Evaluation arose at a time when the main problems were industrial brownfields and their regeneration for business use. This assessment is simple and based on one criterion, which is transport accessibility. For the current situation many different types of brownfields in databases), however, the definition according to good transport accessibility is inaccurate. May even be misleading due to the unclear future of the location. For example, a location that will be transformed into a park or a playground in the future does not need good transport accessibility [20].

The biggest inspiration was the criteria according to Votoček [29] mainly due to the wider context of the connection of potential with the socio-economic development of the municipality.

Category D was approached separately. The need to define hazardous areas or sites was key information. It was necessary to identify those to which, regardless of potential and returns, attention should be paid in the interests of the safety of the population. The hazard is posed by migrating contamination from the site, but also by unsecured parts of the structure falling onto the pavement.

\subsection{Categorization Criteria}

Since 2008, when the database of brownfields in the Moravian-Silesian region was created, we have been trying to divide brownfields according to different methodologies. But it has not been possible to set up a system that is sustainable in the long term, easy to update and sufficiently informative. In 2016, we decided to focus on the concept of the $A B C$ model, include defining our own criteria.

The methods that have been applied are primarily the authors' own experience based on case studies, where several unofficial case studies have been conducted by the authors over the previous years to identify the reasons for the success or failure of the regeneration process (these have not been published and are not part of any official documents).

Authors have created the following descriptions to categorize them. From this description, simple criteria were proposed.

- Sites marked as A: there is no obvious obstacle that would significantly slow down further use of this site.

- Sites marked as B: these sites have an existing development barrier, which can be removed within a few years.

- $\quad$ Sites marked as C: these sites have a significant development barrier. They are not usable under current conditions.

- Sites marked as D: those that pose a danger. It may be a contamination, but also a building that, with its current state, directly threatens its surroundings. For the most part, this condition is the result of a reluctance to act or accept responsibility. 
The adjustment of the categories was based on objective criteria defining development barriers. The evaluation procedure was carried out by both on-desk analysis and field research. The final adjustment of the categorization was made based on all the collected information and the basis of an expert evaluation.

Three basic objective criteria were established: master plan, ownership, and contamination.

The first were problems related to the function and restrictions defined in the master plan. The master plan determines the possible functions that can be placed on the land (living, industry, recreation etc.) and includes restrictions on use (unacceptable functions, height level of buildings, degree of built-up, etc.). An amendment of the master plan in Czech Republic is defined in Building Act 183/2006 Coll. [37]. In practice change in function (and condition describe in master plan) represents a long-term process lasting many years. An inappropriately chosen function or regulation is a significant development barrier. Brownfields were evaluated according to whether the master plan (a function defined in the master plan for the assessed location) in its current form constituted a major development restriction.

The second criterion was the number of owners. The fewer owners, the more promising the site was for further use. Many owners significantly complicate a possible agreement and reaching a consensus is more difficult [38,39].

For some groups, where it was relevant (for example, industrial areas), the possibility of pollution was assessed. The assessment was based on expert evaluation in the System of Registration of Contaminated Sites in the Czech Republic [40,41].

Subjective criterion was based on field surveys and expert group evaluation. The expert group was composed of experts who are engaged in the regeneration of brownfields in the Moravian-Silesian region.

Detail description of criteria have been published in [42].

\subsection{Defining the Territory in Which the Evaluation of Brownfields Was Carried Out and the} Data Source

To evaluate the categories of brownfields, the area of Functional Urban Area (FUA) Ostrava (part of the Moravian-Silesian region) - the Ostrava agglomeration-was selected. The area consists of 119 municipalities and has 965,338 inhabitants. It concentrates $86 \%$ of the population of the Larger Urban Zone Ostrava and 79\% of the population of the Moravian-Silesian region (with $35 \%$ of its territory). The population density in FUA is approximately 509 inhabitants per $\mathrm{km}^{2}$ [43].

This territory was also chosen because it is an ITI area (integrated territorial investment) in the Moravian-Silesian region. (FUA and ITI are defined for the same territory) (Figure 1). This agglomeration is a compact area with a very high daily interaction between municipalities within the country and the core of the agglomeration; also, this area is relatively closed internally. It is also the area with the highest growth potential in the region.

The brownfield analysis concerns the Moravian-Silesian region and is based on the Moravian-Silesian Investments and Development (MSID) internal database. Through its organization, the Moravian-Silesian region manages a database of brownfields, which can be closely monitored in a new map application created for these purposes [44].

This database has many years of tradition and keeps a record of brownfields in the Moravian-Silesian region. 


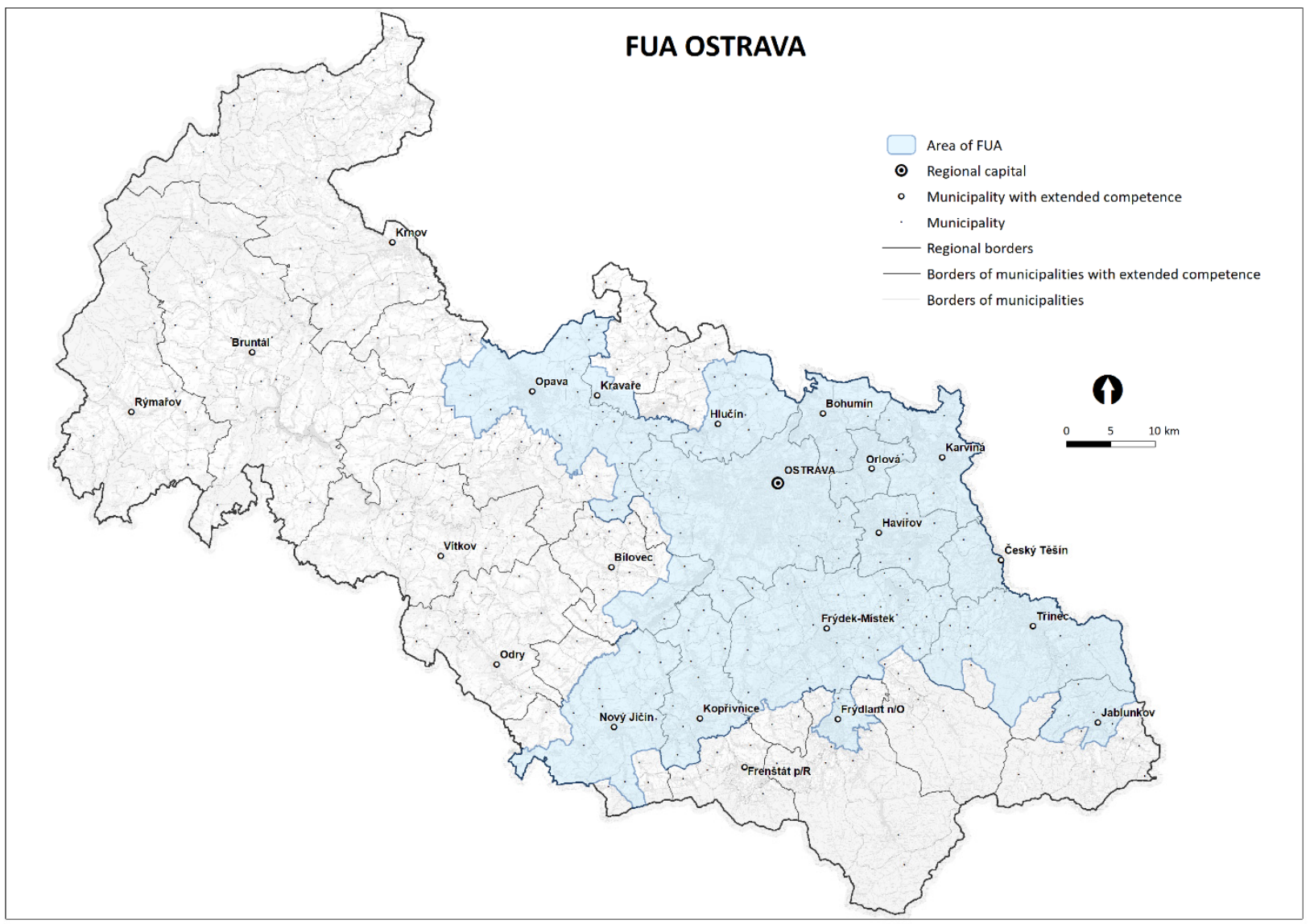

Figure 1. Functional urban area (FUA) Ostrava (information need for create the map can be found in [43]).

2.3. Application of Criteria to the Database of Brownfields in the Moravian-Silesian Region in 2017

The Moravian-Silesian region is one of the regions classified as structurally disadvantaged according to the Strategy of Regional Development of the Czech Republic. There are several buildings and sites in the region that have not been used for a long time and are being neglected.

In 2017, a total of 245 sites showing signs of brownfield were identified in FUA Ostrava. These were previously used, now abandoned or underused areas. The total area was 763.29 ha (Table 2).

Table 2. Overall summary of brownfields for evaluation in 2017.

\begin{tabular}{ccc}
\hline Site Type & Number & Area in ha \\
\hline Site A & 78 & 77.58 \\
Site B & 72 & 16,834 \\
Site C & 41 & 232.82 \\
Site D & 16 & 186.9 \\
Not rated $^{1}$ & 38 & 97.65 \\
Total & 245 & 763.29 \\
\hline
\end{tabular}

${ }^{1} 37$ ha are special military buildings.

Brownfields were divided into the following groups:

- The previous function was housing, administration, or civic amenities

- Heaps and dumps

- Industrial brownfields

- Transport-related brownfields

- Military brownfields 


\section{- Agricultural brownfields}

The evaluation was performed in group (for example, contamination was not assessed for residential buildings). Agricultural and some military brownfields were not evaluated. The reason for this decision was the large variability of buildings in agricultural brownfields which could not be compared objectively (a barn from the 18th century and a large-capacity cowshed from the 1960s). On military brownfields, there was mostly limited access to information.

The aim was to determine what the real development potential was, i.e., for how many brownfields that their regeneration can be expected in a short time. The aim was also to determine the number and area of those sites that require intervention for their development, without which their regeneration cannot be expected in a few years, and to determine how many sites pose a danger that needs to be addressed.

The evaluation procedure is described in [42]. The overall summary is in Table 2.

The distribution of the sites within FUA Ostrava, without unrated sites and including unrated sites, can be seen in Figure 2.

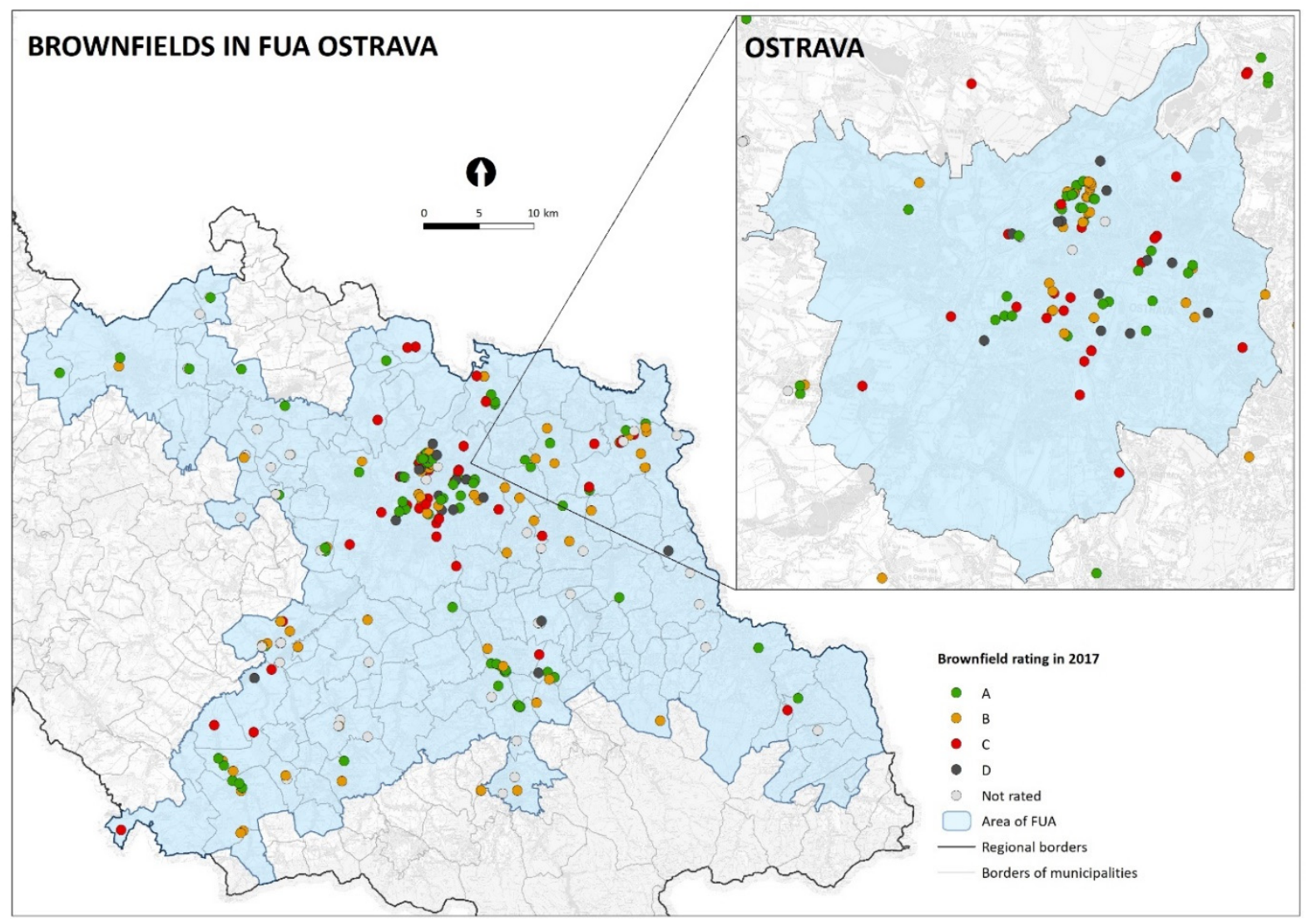

Figure 2. The distribution of the brownfields site within Functional Urban Area (FUA) Ostrava in 2017.

We had to confirm the correctness of our procedure. That is, to confirm that the relatively simple categorization procedure is functional.

It was decided that three years after the categorization (done in 2017) an evaluation would be made to see if the status of these sites in the database had changed. If they are still listed there, it means that they have not been regenerated. Or are some of the sites already removed from the database. This evaluation was done in 2020. For a better understanding of the solution process, a timeline is prepared (Figure 3). 


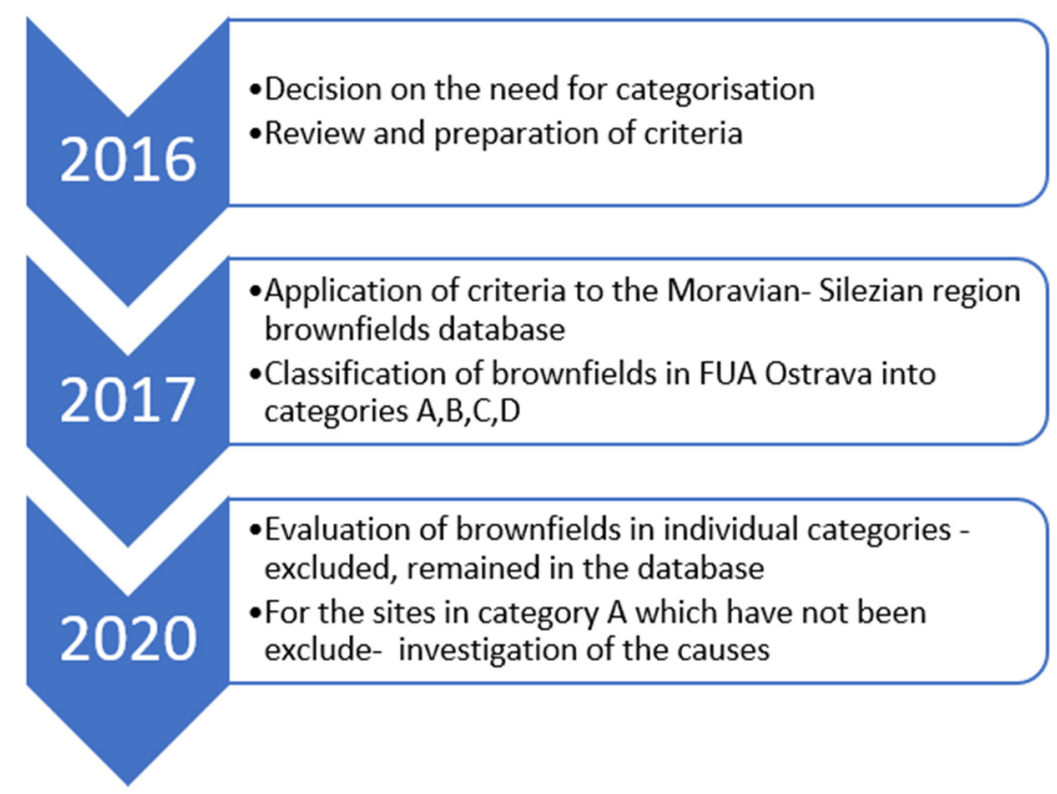

Figure 3. Timeline of the solution procedure.

The aim was to verify whether the procedure chosen in 2017 was correct, that is, the sites had been correctly classified according to potential. The second task was to identify the reason why some sites did not meet the expectations associated with their category, and, possibly, to propose an adjustment to the evaluation criterion.

\subsection{Objectives of Analysis Procedure in 2020}

The aim of the analysis, as noted above, was to verify the evaluation procedure used in 2017 for the division of sites into ABCD based on a comparison of the situation with the real situation in 2020 .

The numbers of sites excluded from the brownfield database between 2017-2020 were evaluated. MSID, as a database administrator, regularly updates the brownfields database and adds some sites and removes others.

MSID excludes sites from the database for the following reasons:

- Fully regenerated,

- Transferred to development area,

- Demolition - the site has become a development area.

Map outputs were processed in the GIS environment, specifically in the ArcMap 10.7. program from ESRI. GPS coordinates (centroids) were assigned to all locations, which were subsequently imported and transformed into individual points.

\section{Results}

The verification occurred in 2020. Only sites evaluated in 2017 were included in the analysis. Individual categories (categories A, B, C, D) were analyses separately. Due to the very short time between categorization and evaluation (three years is a very short time to prepare the regeneration of a brownfield), it was necessary to carry out the verification for nonupdated sites before starting the analysis.

\subsection{Category $A$}

Seventy-eight sites were evaluated in 2017 for category A. Of these, 29 had been excluded from the brownfield database, it means $35.9 \%$ of the sites in category A. The total is $20.48 \mathrm{ha}$. The sites range in size from 0.01 to 3 ha.

Figure 4 shows the location of individual sites, evaluated in the category A in 2017, excluded from the database. These sites are either regenerated or are already developing 
areas. The preparation of the development area was preceded by the complete demolition of the buildings.

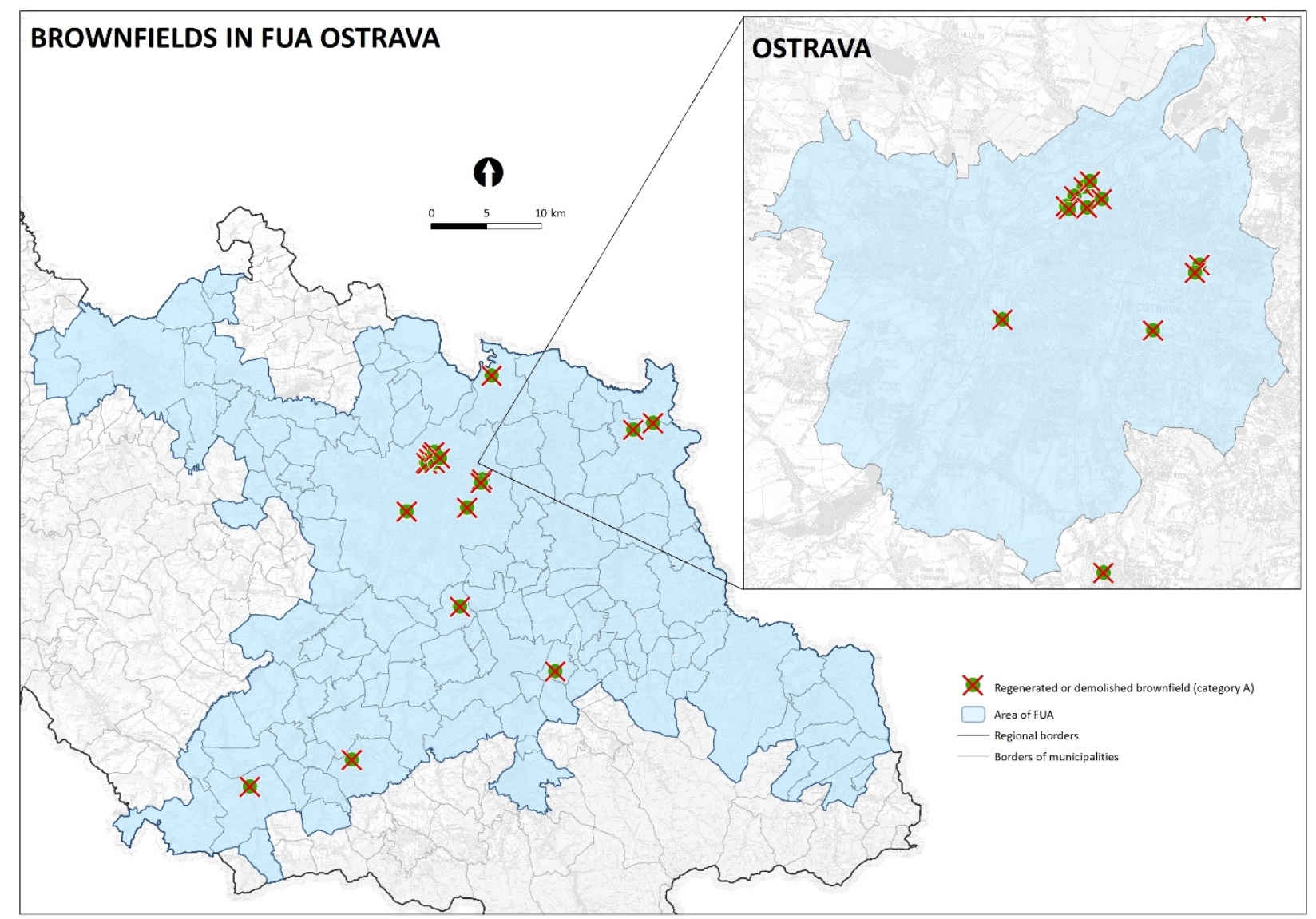

Figure 4. The distribution of sites A excluded from the database (regenerated or after demolished). FUA-functional urban area.

An analysis of excluded sites according to past use was carried out. 17 sites had the past function of housing or civic amenities. Two sites had a transport function and 10 had a former industrial function. In terms of ownership, 19 localities were in private, two in combined, and 6 in public ownership. Only one site had three owners. Two had two owners. The others were owned by only one person.

Even though we could not expect to remove all areas from category A from the database in 3 years. Still, the number seemed small. Because we were concerned that there might be an error in the classification (inclusion in the categories), we made a more detailed analysis of the status of the A sites that remained in the database. It was found out that 15 of them had a project ready (decision making process is finished). These are sites owned by municipalities. It is therefore possible to expect their solution and subsequent regeneration in the foreseeable future.

Brownfield regeneration is a time-consuming process [45] it usually takes up to 10 years. Therefore, it was not possible to assume that $100 \%$ regeneration of category A sites would be achieved within 3 years. For 15 sites, the owners have prepared a project but have not yet started implementation. If we count these localities, we can observe that in 3 years $56 \%$ of the category A sites have been and are ready for regeneration.

\subsection{Category $B$}

Category B sites were selected for further analysis. The analysis showed that from 72 category B sites, a total of 18 sites with a total area of 66 ha have been regenerated or excluded from brownfield database. 
These are majority sites up to 1 ha in size. Other three sites are between 1 and 3.6 ha. The three largest sites are 8.48, 20, and 25.49 ha. When converted to area, these three sites represent $81 \%$ of the area of regenerated or excluded B sites.

In terms of past use, nine sites are former industrial areas, three sites are civic amenities, five of them are transport facilities, and one is a military area. In terms of ownership, four sites are publicly owned and fourteen are privately or combined.

The distribution of sites excluded until 2020 (regenerated or after demolition) from category B in 2017 can be seen in Figure 5. As with category A, these were sites from the central part of the region and from the north-south belt. These were not sites in the more remote parts of the region.

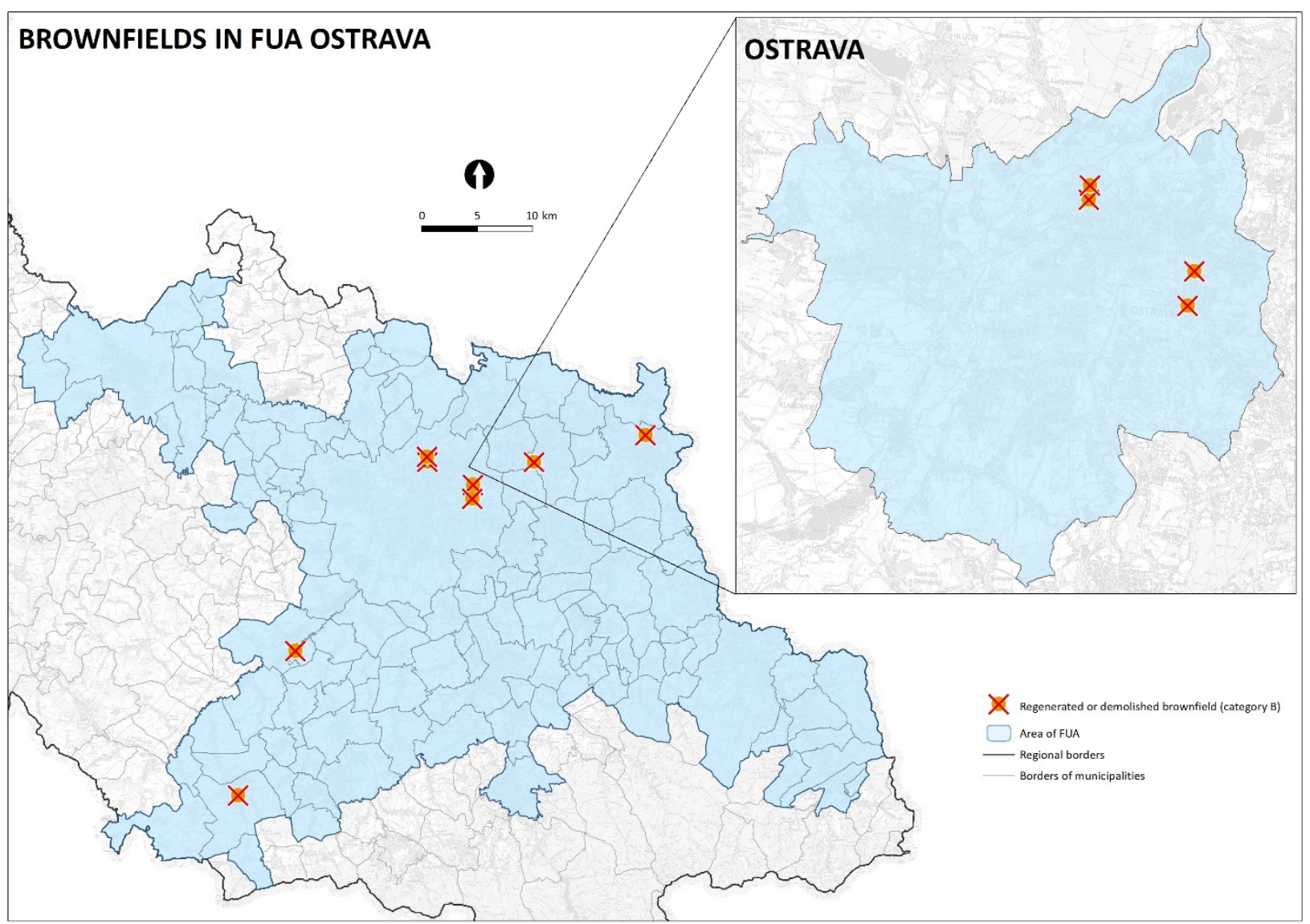

Figure 5. The distribution of sites excluded until 2020 (regenerated or after demolition) from category B in 2017. FUAfunctional urban area.

It was necessary to assess why category B sites were regenerated or excluded, even though the criteria indicated that they were sites with less development potential. An additional analysis of the reasons was carried out. In the first step, attention was paid to the three largest areas. One is a former military complex. The owner, which is the Ministry of the Interior, is a strategic ministry and the buildings it owns are subject to strategic decisions made by the government. It is therefore very difficult to identify planned projects in advance. Regeneration essentially occurred with the support of public finances. Based on this experience, a first recommendation was prepared for the next evaluation, namely: "If the brownfield has past military use and still remains the property of the Ministry of the Interior, we do not recommend evaluating these sites." Two other large sites became part of the transport infrastructure project. Transport infrastructure is built from public funds. Therefore, the original rating in category B is correct. Three other sites owned by municipalities were demolished thanks to the provided extraordinary public subsidies. This, indeed, confirmed the need for public finances to enter the regeneration process. 
The analysis of the other removed sites was more interesting. As the ownership structure suggests, there was an interest in regeneration among private entities. This was due to the steady increase in property prices until 2020, especially the increase in greenfield prices. During 2019, looser monetary conditions contributed to the continued rise in property prices in most EU countries. The average year-on-year dynamics of prices decreased slightly during 2019 compared to 2018, but even so, in the third quarter of 2019 prices grew by around 9\% in the Czech Republic [46]. This made greenfield construction significantly more expensive and brownfield sites became more interesting.

\subsection{Category $C$}

An analysis of the status of sites in category $\mathrm{C}$ was also done. Out of a total of 41 sites, six had been regenerated ( $6.8 \mathrm{ha}$ ), which makes up 3\% of the total area. Three sites had an industrial past, two were military and one was civic amenities. As these were sites with no potential, it was necessary to analyses in more detail the fact why the sites had been successfully regenerated. For the two industrial areas, the reason for their inclusion in category C in 2017 was primarily their location in a large complex of industrial buildings. The owner of this property had significant financial problems and the areas had an industrial past of more than 150 years. Their owner had not done anything with the property for a long time and the condition of the buildings was very poor. Between 2017 and 2020, the original owner began selling individual buildings and areas to meet the creditors' requirements. Two military buildings were modified by the owner. In one case, it was a complex demolition and release of land for other uses. This was therefore again an investment from public funds, i.e., from the Ministry of the Interior.

\subsection{Category D and Summary of All Categories}

As part of the validation of the applied method for categorization, sites categorized as D were also evaluated. Out of a total of sixteen, five sites were excluded (82.16 ha), i.e., $43.95 \%$ of the area of all sites D. Sites D were included mainly due to the existence of a danger to society. Two sites used to be old landfills, which were reclaimed thanks to public funds. One privately-owned site received a subsidy of $20 \%$ of the costs of the remediation of the area. The current did not cause the pollution. One site has been demolished and is privately owned. The private owner is the dominant owner in the area and invests in its regeneration. One site has been regenerated under the Ecological Agreement between the owner and the state.

The criteria for category $\mathrm{D}$ sites have been set correctly. Classification in category D does not express the development potential, but it is a special group of brownfields that are dangerous and should be given priority. The criteria do not reflect the potential for regeneration but provide important information for public administration.

Figure 6 shows the connection of the state of brownfields with marked discarded brownfields in 2020. All assessed sites are recorded in the figure. The cross-hatching indicates that the site has been removed from the database. For better clarity, Ostrava is shown in more detail. Ostrava is a regional city. In the figure we can see that the excluded sites are concentrated in Ostrava which corresponds to the status of a regional city. In the northern part of the region there is a higher concentration of decommissioned sites in Bohumín. Referring to the local knowledge of the authors, this is a logical result of many years of active policy of the city of Bohumín in the field of brownfields regeneration.

\subsection{Suggestion for Discussion}

The search for ways to define, describe or assess brownfield potential within databases varies depending on the number of brownfield sites, the approach of government, the existence of databases and a range of other factors. Already the word "brownfield" as a term has several ways of understanding [47] and always fits the local context [12]. Differently defined and quantified criteria appear in a few authors [48]. What the authors of the article find necessary to discuss is the inclusion of subjective assessment. From a purely 
technical point of view, it is a variable that cannot be quantified and therefore cannot be compared. This criterion is based on a very good knowledge of the site itself, but also of its surroundings, including several historical contexts. From the point of view of many years of experience, it is the subjective criterion based on local knowledge that appears to be the key.

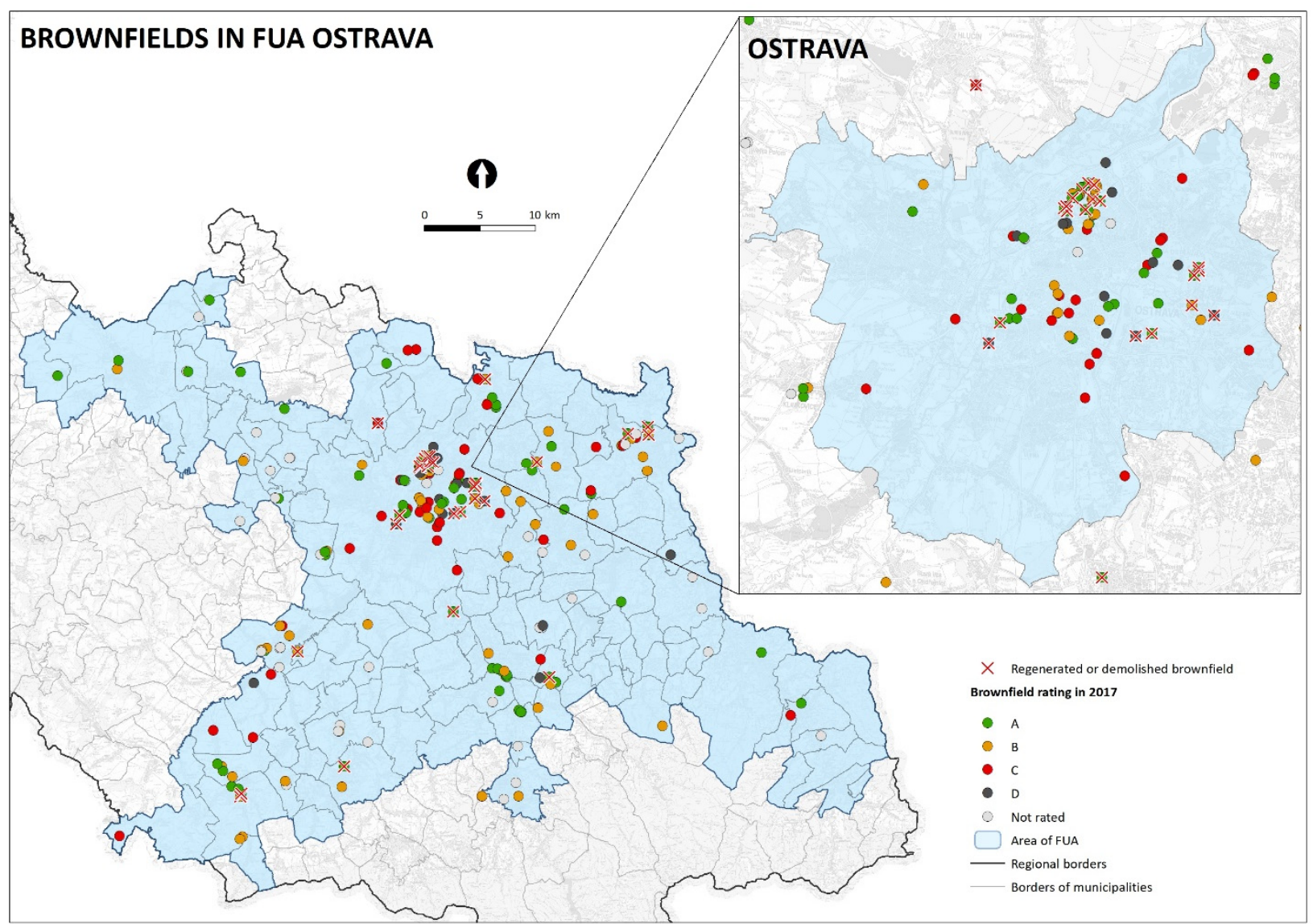

Figure 6. The state of brownfields with marked discarded brownfields in 2020. FUA—functional urban area.

To discuss how to determine the potential for brownfield regeneration, it is necessary to decide whether the potential is hypothetical or practical. The hypothetical potential is based on several research papers where, for example, the link to the business environment is mentioned as one of the key indicators [49]. Even more frequently, location within an area or a municipality is mentioned, for example, the location in relation to the center of the municipality [50]. These criteria are supported by statistical analysis of already regenerated brownfields. It is based on the characteristics of already regenerated areas. In this hypothetical view, they have a high regeneration potential locality in good transport accessibility and a good business environment or educational structure. [51]. The regenerated localities had these characteristics. However, the problem is the group of localities that have these qualities and at the same time are not regenerated. They have a regeneration potential hypothetical and they do not have a regeneration potential practical. Our research has focused specifically on the practical potential, that is, focusing on the internal barriers of the sites. In the future, it will be necessary to work with municipal representatives to determine the optimal ratio between hypothetical and practical development potential.

\section{Conclusions}

Based on the analysis of the change in the status of the database of brownfields for the Moravian-Silesian region at FUA Ostrava between 2017 and 2020, it was found that the set classification is functional and gives a good idea of the potential of the area for regeneration. 
The assessment system is set up to be universally applicable in other cities. It can be said that the whole assessment procedure is additionally applicable-using the same data information-outside the Moravian-Silesian region.

It is the subjective criterion, which is based on knowledge of other not always officially supportable contexts, that is probably the key. Database administrators, have such knowledge.

The fact that not all A sites have been solved can be attributed to the short time interval (3 years), which is very short in the regeneration process. Projects have been prepared for several sites. These are mainly sites owned by municipalities that wanted to draw funds from the project of the Ministry of Regional Development, the first year of which was announced in 2019.

The reasons for the unforeseen interest in 2017 (Sites B and C) were mainly a reflection of price increases in the property market. However, it was also evidence that some sites needed intervention for development. In the case of category $C$ sites, this was only a very small number. The correct settings can also be seen here. Public investment has made a significant contribution to regenerated sites. We do not recommend that sites owned by the Home Office are assessed for further development.

The overall state of the property market is reflected in the brownfield market. In times of high prices, there is more interest in brownfield sites. For example, the lack of ready sites for residential development and the complexity of the administrative processes are causing a slowdown in the construction of new housing in metropolitan areas, thereby driving up prices.

For hazardous sites (category D), environmentally burdened sites still predominate, but they are being addressed. This is even though the issue of removing old environmental burdens is not regulated by law. The system of registration of contaminated sites in the Czech Republic is at a high level and the database contains a lot of data on individual sites.

The authors consider the main contribution of their research to be the creation of a simple, easy-to-apply classification of brownfields and the verification of its functionality. The functionality was verified at FUA Ostrava. Currently, the entire database of the Moravian-Silesian region is being reclassified and its evaluation should take place in 2023. We expect that in cooperation with other regions we or direct representatives of the database administrator will apply our procedure to other databases in the Czech Republic. The application outside the Czech Republic may be difficult due to the criterion-the master plan. Its concept may vary from country to country.

Our method of classification can be used by all administrators of brownfields databases in the Czech Republic, but we expect to use it mainly at the level of cities and regions.

Author Contributions: B.V., conceptualization, methodology, formal analysis, investigation, validation, resources, writing-original draft preparation review and editing; I.T., conceptualization, methodology, formal analysis, investigation, resources, writing - original draft preparation, project administration; R.F., methodology, investigation, resources, data curation, GIS application, visualization, map preparation. All authors have read and agreed to the published version of the manuscript.

Funding: This research was funded by LUMAT project (LUMAT - Implementation of Sustainable Land Use in Integrated Environmental Management of Functional Urban Areas-CE89).

Institutional Review Board Statement: Not applicable.

Informed Consent Statement: Not applicable.

Data Availability Statement: The data presented in this study are available on request from the corresponding author. The data are not publicly available due to they are only in Czech language and contain personal comments [insert reason here].

Conflicts of Interest: The authors declare that they have no known competing financial interests or personal relationships that could have appeared to influence the work reported in this paper. 


\section{References}

1. Vojvodikova, V. Development of the Region Affected by Mining Activities with a Focus on the Use of Former Mining Sites. Ph.D. Thesis, VŠB- Technical University of Ostrava, Ostrava, Czech Republic, 2001.

2. Tvrdíková, A. Analýza Brownfields Na území Karlovarského Kraje. (Analysis of Brownfields in the Karlovy Vary Region), Ústí Nad Labem. Bachelor's Thesis, Univerzita Jana Evangelisty Purkyně, Ústí nad Labem, Czech Republic, 2018.

3. Analýza Brownfieldů na Uzemé Města Vsetína, (Analysis of Brownfields in Vsetín). Available online: https://www.vsetin.cz/ assets / File.ashx?id_org=18676\&id_dokumenty=498577 (accessed on 22 September 2021).

4. Vráblík, P. Regenerace Brownfieldů v Modelové Oblasti Podkrušnohoří a Možnost Jejich Revitalizace. (Regeneration of Brownfields in the Podkrušnohoři Model Area and the Possibility of Their Revitalisation); Univerzita Jana Evangelisty Purkyně: Ústí nad Labem, Czech Republic, 2009.

5. Bergatt, J.; Bergatt, W.; Votoček, J. Analýza Brownfieldů v ORP Ústí nad Labem a ve Statutárním Městě Ústí nad Labem (Analysis of Brownfields in the Ústí nad Labem Region and the Statutory City of Ústí nad Labem). Available online: https: / / www.usti-nad-labem.cz/files / analyza-p.pdf (accessed on 16 May 2021).

6. Kašpar, V. Brownfieldy v Pardubickém kraji. (Brownfields in the Pardubice Region). Bachelor's Thesis, VŠB-Technical University of Ostrava, Ostrava, Czech Republic, 2021. Available online: http://hdl.handle.net/10084/144355 (accessed on 19 September 2021).

7. Analýza, B.F. Jihomoravská Rozvojová Agentura. Available online: https://www.rrajm.cz \T1 guilsinglrightdownload $\backslash \mathrm{T} 1$ $\backslash$ guilsinglrightanalyza-bf-2019 (accessed on 19 September 2021).

8. Piskorz, J. Support for Regeneration of Brownfields in the Moravian-Silesian Region. In Proceedings of the Seminář-Brownfields, Ostrava, Czech Republic, 22 October 2015.

9. Glumac, B.; Han, Q.; Schaefer, W. 'Stagnation in Brownfield Redevelopment', World Academy of Science, Engineering and Technology, Open Science Index 78. Int. J. Econ. Manag. Eng. 2013, 7, 1471-1478. [CrossRef]

10. Černík, J.; Kunc, J.; Martinát, S. Territorial-Technical and Socio-economic Aspects of Successful Brownfield Regeneration: A Case Study of the Liberec Region (Czech Republic). Geogr. Tech. 2016, 11, 22-38. [CrossRef]

11. Osman, R.; Frantal, B.; Klusáček, P.; Kunc, J.; Martinát, S. Factors Affecting Brownfield Regeneration in Post-Socialist Space: The Case of the Czech Republic. Land Use Policy 2015, 48, 309-316. [CrossRef]

12. Turečková, K.; Nevima, J.; Škrabal, J.; Martinát, S. Uncovering Patterns of Location of Brownfields to Facilitate Their Regeneration: Some Remarks from the Czech Republic. Sustainability 2018, 10, 1984. [CrossRef]

13. Ferber, U.; Grimski, D.; Millar, K.; Nathanail, P. Sustainable Brownfield Regeneration: CABERTNET Network Report; University of Notthingham: Notthingham, UK, 2006. Available online: https://www.yumpu.com/en/document/view/43804816/sustainablebrownfield-regeneration-cabernet-network-report (accessed on 22 September 2021).

14. Ferber, U.; Tomerius, S. Brownfield Redevelopment. In The Changing Boundaries of Social Enterprises; OECD Publishing: Paris, France, 2003; pp. 125-158. [CrossRef]

15. Nathanail, P.; Thornton, G.; Millar, K. "MODEL 2: CABERNET A-B-C Model”. In What's in a Word: UK and International Definitions of 'Brownfield'. Sustainability 2003, 4, 43-45.

16. Garb, Y.; Jackson, J. Brownfields in the Czech Republic, 1989-2009: The Long Path to Integrated Land Management. J. Urban Regen. Renew. 2010, 3, 263-276. [CrossRef]

17. Pavolová, H.; Csikósová, A.; Bakalár, T. Brownfields As a Tool for Support of Regional Development of Slovakia. Appl. Mech. Mater. 2012, 209-211, 1679-1683. [CrossRef]

18. Pizzol, L.; Zabeo, A.; Klusáček, P.; Giubilato, E.; Critto, A.; Frantal, B.; Martinát, S.; Kunc, J.; Osman, R.; Bartke, S. Timbre Brownfield Prioritization Tool to Support Effective Brownfield Regeneration. J. Environ. Manag. 2016, 166, 178-192. [CrossRef]

19. Navratil, J.; Krejci, T.; Martinat, S.; Pasqualetti, M.J.; Klusáček, P.; Frantal, B.; Tochackova, K. Brownfields Do Not “only Live twice": The Possibilities for Heritage Preservation and the Enlargement of Leisure Time Activities in Brno, the Czech Republic. Cities 2018, 74, 52-63. [CrossRef]

20. Bergatt Jackson, J. Brownfields Snadno a Lehce. (Brownfields Easily and Simply); IURS: Prague, Czech Republic, 2004 ; pp. 6-18.

21. Petríková, D. Land Circulation: From Brownfields to Recultivation of Landscape. Terra Spectra. 2009, 2, 49-52.

22. Ferber, U.; Nathanail, P.; Bergatt, J.J.; Gorski, M.; Krzywon, R.; Drobiec, L.; Petríková, D.; Finka, M. Brownfields Handbook: Cross-Disciplinary Educational Tool Focused on the Issue of Brownfields Regeneration. Available online: http://fast10.vsb.cz/ lepob/index1/handbook_eng_screen.pdf (accessed on 2 October 2020).

23. Petriková, D. Revitalizácia brownfield lokalít ako súčast' stratégie územného rozvoja (Revitalization of brownfield sites as part of the territorial development strategy). In Trajektórie Územného Rozvoja; SPECTRA, Centre of Excellence: Bratislava, Slovak, 2006; pp. 29-46. ISBN 978-80-88999-31-7.

24. Butzin, B.; Franz, M.; Noll, H.P. Strukturwandel im Ruhrgebiet unter Schmrumpfungs-bedingungen. In Patchwork-Managemen als Herausfor-Derung. Zetschrift für Wirtschaftsgeographie; De Gruyter: Berlin, Germany, 2006; Volume 50, No. 3/4; pp. 258-276. ISSN 0044-3751.

25. Ferber, U.; Schlappa, H. Managing Brownfield Land in Stagnant Land Markets. In Future Directions for the European Shrinking City; Routledge: London, UK, 2016; ISBN 9781315747286. 
26. Bergatt Jackson, J.; Votoček, J. Metodika Inventarizace Brownfieldů v ORP (Methodology of Brownfields Inventory in ORP) Magistrát Města Ústí nad Labem, Czech Republic. 2010. Available online: https://www.usti-nad-labem.cz/files/metodika-p.pdf (accessed on 9 July 2020).

27. Petríková, D. Klasifikácia a hodnotenie možností regenerácie brownfieldov (Classification and evaluation of brownfield regeneration possibilities). Urbanita 2011, 26, 10-13.

28. Doleželová, L.; Hadlač, M.; Kadlecová, M.; Martinát, S.; Polednik, M. Redevelopment potential of brownfields: A-B-C classification and its practical application. E+M Ekonomie a Manag. 2014, 17, 34-44. [CrossRef]

29. Votoček, J. Ǩešení problematiky Brownfields. Ph.D. Thesis, Faculty of Civil Engineering, VŠB-Technical University of Ostrava, Ostrava, Czech Republic, 2011.

30. Kraft, J. Úloha trhu při systematické revitalizaci brownfields (The role of the market in the systematic revitalization of brownfields). E+M Ekonomie a Manag. 2005, 8, 28-33.

31. De Sousa, C.A. Turning Brownfields into Green Space in the City of Toronto. Landsc. Urban Plan. 2003, 62, 181-198. [CrossRef]

32. Czechinvest Agency. National Strategy for Brownfield Regeneration (Národní Strategie Regenerace Brownfield); Ministry of Industry and Trade: Prague, Czech Republic, 2008; p. 13.

33. Bartke, S. Valuation of Market Uncertainties for Contaminated Land. Int. J. Strateg. Prop. Manag. 2012, 15, 356-378. [CrossRef]

34. Krzysztofik, R.; Kantor-Pietraga, I.; Spórna, T. A Dynamic Approach to the Typology of Functional Derelict Areas (Sosnowiec, Poland). Morav. Geogr. Rep. 2013, 21, 20-35. [CrossRef]

35. Franz, M.; Pahlen, G.; Nathanail, P.; Okuniek, N.; Koj, A. Sustainable Development and Brownfield regeneration. What Defines the Quality of Derelict Land Recycling? Environ. Sci. 2006, 3, 135-151. [CrossRef]

36. Modica, M. Industrial Brownfield Sites in the Alps. A First Quantitative Overview and Potential Implications for Regional Development. Rev. De Geacute Ographie Alp. 2019, 107, 1. [CrossRef]

37. Building Act No.183/2006 Coll. Available online: https://www.mmr.cz/MMR/media/MMR_StaryWeb/import/\%c3\%9 azemn \%c3\%ad\%20p1\%c3\%a1nov\%c3\%a1n\%c3\%ad\%20a\%20stavebn\%c3\%ad \%20\%c5\%99\%c3\%a1d/Pr\%c3\%a1vo\%20a\%20 legislativa/P\%c5\%99ehled\%20platn\%c3\%bdch\%20pr\%c3\%a1vn\%c3\%adch\%20p\%c5\%99edpis\%c5\%af/SZ_angl.pdf (accessed on 6 October 2021).

38. Common Obstacles to Brownfield Redevelopment. Available online: https://mnbrownfields.org/land-recycling-101/commonobstacles-to-brownfield-redevlopment/ (accessed on 9 July 2020).

39. Coffin, S.L.; Shepherd, A. Barriers to Brownfield Redevelopment: Lessons Learned from Two Great Lakes States. Public Work. Manag. Policy 1998, 2, 258-266. [CrossRef]

40. Ministry of the Environment of the Czech Republic. Metodický Pokyn MŽP k Plnění Databáze SEKM Včetně Hodnocení Priorit (Methodological Instruction of the Ministry of the Environment on the Implementation of the SEKM Database, Including the Evaluation of Priorities). Available online: https:/ / www.mzp.cz/cz/metodiky_ekologicke_zateze (accessed on 1 October 2020).

41. SEKM-Systém Evidence Kontaminovaných Míst (SEKM-Contaminated Sites Registration System). Available online: https: //www.sekm.cz/portal/ (accessed on 2 October 2020).

42. Vojvodikova, B.; Ticha, L.; Fojtik, R.; Szeligova, N. Brownfields in Function Urban Area Ostrava. IOP Conf. Ser. Mater. Sci. Eng. 2019, 471, 102023. [CrossRef]

43. Strategie ITI Ostravské Aglomerace-Integrovaná Teritoriální Investicei (Strategy TI Ostrava Agglomeration-Integrated Territorial Investment), Úřad Regionální Rady Regionu Soudržnosti Moravskoslezsko, Pricewaterhouse Cooopers, s.r.o., Profak-tum, s.r.o., Ostrava Czech Republic. 2015. Available online: https://itiostravsko.cz/wp-content/uploads/2020/05/Strategie-ITIostravsk-aglomerace-FINAL-03_11_2016.pdf (accessed on 6 October 2020).

44. Brownfieldy v Moravskoslezském Kraji, Brownfields in Moravian Silezian Region. Available online: https://geoportal.msk.cz/ Public/Apps/brownfield/index.html (accessed on 6 May 2020).

45. Martinec, P. Termination of Underground Coal Mining and Its Impact on the Environment; Anagram: Ostrava, Czech Republic, 2006; ISBN 80-7342-098-8.

46. Trend Report. Available online: http://artn.cz/wp-content/uploads/2020/02/TrendReport-2020_CZ-1.pdf (accessed on 2 October 2020).

47. Ahmad, N.; Zhu, Y.; Ibrahim, M.; Waqas, M.; Waheed, A. Development of a Standard Brownfield Definition, Guidelines, and Evaluation Index System for Brownfield Redevelopment in Developing Countries: The Case of Pakistan. Sustainability 2018, 10, 4347. [CrossRef]

48. Cotič, B.; Momirski, L.A. Inventory of Brownfield Sites in Slovenia. Proster 2020, 28, 166-179. [CrossRef]

49. Frantál, B.; Kunc, J.; Nováková, E.; Klusáček, P.; Martinát, S.; Osman, R. Location Matters! Exploring Brownfields Regeneration in a Spatial Context (A Case Study of the Southern Moravian Region, Czech Republic). Morav. Geogr. Rep. 2013, 21, 5-19.

50. Lange, D.; McNeil, S. Clean It and They Will Come? Defining Successful Brownfield Development. J. Urban Plan. Dev. 2004, 130, 101-108. [CrossRef]

51. Frantal, B.; Greer-Wootten, B.; Klusáček, P.; Krejčí, T.; Kunc, J.; Martinát, S. Exploring Spatial Patterns of Urban Brownfields Regeneration: The Case of Brno, Czech Republic. Cities 2015, 44, 9-18. [CrossRef] 